\title{
ASSESSMENT OF COMPRESSION BEHAVIOUR OF COMPACTED SOILS
}

\author{
U. Venkata Rathnam \\ Research Scholar, Department of Civil Engineering, \\ SVU College of Engineering, Tirupati, Andhra Pradesh, India \\ Dr. K. Nagendra Prasad \\ Professor, Department of Civil Engineering, \\ SVU College of Engineering, Tirupati, Andhra Pradesh, India
}

\begin{abstract}
The soil compaction is an important engineering application in many geotechnical issues related infrastructure development. Millions of cubic meters of soils are subject to compaction all over the world in the construction of flyovers, embankments, roads and irrigation structures. Compaction improves the stability, strength characteristics and reduces the permeability. Though the strength development as a result of compaction is well studied, compressibility characteristics need much closer examination for enabling better comprehension in the analysis and design of soil structures. A limited experimental investigation is taken up in the present study to understand the compressibility behaviour of compacted soils. The soils from eight different locations in the region of Tirupati have been selected based on inherent variations represented by grain size and plasticity characteristics for the purpose of the study. The soils are classified predominantly as Clayey Sands (SC) to Clay with High Compressibility (CH) as per Indian Standard classification (IS 1498-1970) [4]. The oedometer compression tests are conducted on soils compacted to Proctor's maximum dry density as per IS 2720 Part-7 1980 [11]. The compressibility behaviour is analysed and a step wise procedure is proposed for assessing the compressibility behaviour of compacted soils for use by practicing engineers.
\end{abstract}

Keywords: compacted soils, analysis and prediction, compressibility behaviour, phenomenological model.

Cite this Article: U. Venkata Rathnam and Dr. K. Nagendra Prasad, Assessment of Compression Behaviour of Compacted Soils. International Journal of Civil Engineering and Technology, 11(3), 2020, pp. 1-12.

https://iaeme.com/Home/issue/IJCIET?Volume=11\&Issue=3

\section{INTRODUCTION}

Compaction of soil is one of the important geotechnical engineering applications in the development of infrastructure projects. Compaction is a process whereby soil particles are 
brought together by application of stress leading to expulsion of air in the interstices of soil mass enabling densification. Millions and millions of tonnes of soil masses are compacted around the world in geotechnical engineering practice involving construction of roads, flyovers retaining structures and many land reclamation works. As soil is naturally occurring material, its formation depends on many genetically different forms and is quite varied from place to place. It therefore, becomes necessary to analyze the compressibility data in a systematic manner and propose a logical approach to capture the behaviour in terms of easily comprehensible way for use by field engineers. Though many a researcher focused on shear strength behaviour of compacted soils, it has not yet been possible to bring out the compressibility behaviour in a unified and comprehensive manner. The present paper focuses on proposing methodology for determining the compressibility behaviour by considering pre yield and post yield behaviour of the soil. The data of eight different soils with inherent variations are presented for the purpose of the study. The data of six soils are used for proposing the method and the remaining soil data has been used to predict the behaviour from the method proposed.

\section{BACKGROUND INFORMATION}

The shear strength and compressibility, both parameters are the most essential characteristics of a cohesive soil mass in the design and analysis of many civil engineering structures like dams, highways, embankments and foundations. Keeping in view the feasibility of the usage of compacted clayey soils in the fields and scarcity of literature on the induced yield stress, compression index before and after yield and stress paths the objective of the present study are:

- To investigate the yield stress behavior against unconfined compressive strength and initial void ratio.

- To investigate the relationship between compression indices $(\mathrm{Cc} 1$, before yield and Cc2 after the yield stress) to stress paths.

Venkata Ratnam and Nagendra Prasad proposed an equation for correlating Cc with modified liquid limit, (Venkata Ratnam and Nagendra Prasad, 2019) [18]. Rehman et al developed three predictive models of yield stress $(\sigma y)$ by using Plasticity index, optimum water content and maximum dry unit weight as independent variables with reliable prediction accuracy, (Rehman et al., 2018) [15]. Compression Index (Cc) is a significant factor for assessment of settlement due to primary consolidation settlement of clays. Assessment of its value through laboratory test is time consuming, expensive and lengthy task. The present study is also an attempt to predict it with the help of initial void ratio, (Rakesh kumar et al., 2016) [14]. ChaoYang et al., (2014) [3], emphasized the acknowledged dependence of the shear strength on the compression behavior of soils in critical state soil mechanics. Akayuli and Ofosu used linear regression analysis to establish empirical correlations relating Compression Index (Cc) and Index properties of soil, using Birimian phyllites samples found in Kumasi city, Ashanti region (Ghana). About 90 samples were tested, out of which 60 samples were used in regression analysis and 30 samples were used to validate the obtained correlation, (Akayuli and Ofosu, 2013) [2]. Nagendra Prasad et al.,(2013) [13], based on detailed experimental investigation and analysis of test results, the compression behavior depicts initially stiff response up to a normal stress value and shows greater degree of compression beyond this stress value. The same compression behavior is noticed with respect to all the soil samples tested. Tiwari and Ajmera conducted a research by using different proportions of montmorillonite, Illite, kaolinite and quartz at an initial water content equal to liquid limit. They proposed two different sets of equations for correlating $\mathrm{Cc}$ with initial void ratio and liquid limit. (Tiwari and Ajmera, 2012) [17]. 
The aim of present work is to use a more undeviating approach to portray the compression behavior of compacted soils, and hope fully is able to improve predictions of the compression behavior. Validation against a set of experimental data with different stress paths for three different types of soils will be carried out including one soil data from literature. A few discussions and an outline of the main result will conclude this paper.

\section{MATERIALS AND METHODS}

The soil samples from eight different locations were brought to laboratory after removing the top filled up soil. The soils are brought to the laboratory for further processing. The soil samples were air dried and sieved through $20 \mathrm{~mm}$ sieve and the fraction passing through the $20 \mathrm{~mm}$ sieve has been used for conducting the experimental study.

The experimental investigation considers soil samples from eight different locations of Tirupati Region. The soils are classified as Clayey Sand (SC) to Clay with Low Compressibility (CL). The fine fraction ranges from 37-88\%. The Liquid Limit values range from $30 \%$ to $80 \%$ and the Plasticity Index ranges from $8 \%$ to $60 \%$. The properties represent inherent variability though categorized into similar broad classification as per IS 1498-1970 [4]. The soils are of this type are typical of the soils encountered in the region. The soils tested cover wide spectrum of soil variety and the experimental results on these soils provide basis for analyzing and predicting the soil behaviour as any soil found locally would fall into one of these categories.

Laboratory tests were carried out as follows:

(a) To determine Physical Properties of Soil \{Classification\}:

- Consistency limit tests [Atterberg];

- Particle size analysis

(b) To determine Mechanical Properties of Soils:

- Compaction,

- Oedometer Compression

All tests were performed as per bureau of Indian Standard Specifications as mentioned in the Table 1. The Basic properties of the soils are presented in Table 2

Table 1 Tests Conducted

\begin{tabular}{|l|l|}
\hline Test Conducted & IS code of Practice* \\
\hline Grain size Distribution & IS 2720-4:1985 \\
\cline { 1 - 2 } Liquid Limit & IS 2720-5:1985 \\
\hline Plastic Limit & IS : 2720 (Part III/Sec 1-1980 \\
\hline Specific Gravity & IS 2720-40:1985 \\
\hline Free Swell Index & \multirow{2}{*}{ IS 2720-7:1980 } \\
\cline { 1 - 2 } Maximum Dry Density & IS: 2720 (Part. XV) 1986 \\
\hline Oedometer Test & \\
\hline
\end{tabular}

$*[8,10,7,9,11$, and 6$]$ 
Table 2 Basic properties of the soils tested

\begin{tabular}{|c|c|c|c|c|c|c|c|c|c|}
\hline S.No & Properties & S1 & S2 & S3 & S4 & S5 & S6 & S7 & S8 \\
\hline 1 & Specific Gravity & 2.74 & 2.63 & 2.56 & 2.76 & 2.73 & 2.65 & 2.65 & 2.5 \\
\hline \multirow{5}{*}{2} & Gravel (\%) & 9.20 & 1.20 & 3 & 1.16 & 1.20 & 4.20 & 2.22 & 6.41 \\
\hline & Sand $(\%)$ & 47.00 & 24.00 & 19 & 63.47 & 62.10 & 47.40 & 47.17 & 14.90 \\
\hline & Silt (\%) & 37.42 & 34.31 & 21.49 & 20.46 & 24.49 & 30.75 & 32.26 & 65.91 \\
\hline & Clay $(\%)$ & 6.38 & 40.49 & 56.51 & 14.91 & 12.21 & 17.65 & 18.34 & 12.78 \\
\hline & $\%$ Passing $425 \mu$ & 66.2 & 86.74 & 93.51 & 52.25 & 58 & 68 & 85.43 & 82.62 \\
\hline \multirow{3}{*}{3} & Liquid Limit (\%) & 62.00 & 41.50 & 51.00 & 32.50 & 81.50 & 65.50 & 60.00 & 55.00 \\
\hline & Plastic Limit (\%) & 27.00 & 21.00 & 19.00 & 24.60 & 21.00 & 19.00 & 16.27 & 17.00 \\
\hline & Plasticity Index (\%) & 35.00 & 20.50 & 32.00 & 20.50 & 60.50 & 46.50 & 43.73 & 38.00 \\
\hline 4 & $\begin{array}{l}\text { IS Classification } \\
(1498-1970)\end{array}$ & $\mathrm{SC}$ & CI & $\mathrm{CH}$ & SM & $\mathrm{SC}$ & $\mathrm{SC}$ & $\mathrm{SC}$ & $\mathrm{CH}$ \\
\hline 5 & Free Swell Index, $\%$ & 110 & 108 & 105 & 60 & 182 & 160 & 135 & 110 \\
\hline 6 & $\begin{array}{l}\text { Maximum Dry } \\
\text { Density, } \mathrm{kN} / \mathrm{m}^{3}\end{array}$ & 19.00 & 18.12 & 17.90 & 19.22 & 19.50 & 18.80 & 18.75 & 18.10 \\
\hline 7 & $\begin{array}{l}\text { Optimum Moisture } \\
\text { content, } \%\end{array}$ & 15.00 & 17.00 & 16.50 & 14.50 & 14.00 & 14.50 & 15.50 & 16.90 \\
\hline
\end{tabular}

\subsection{Oedometer Test}

Soils samples are prepared by compacting them at respective moisture contents. The soil samples have been extracted by gradually inserting consolidation ring by gentle pressing with hands and trimming any excess material, if any. These samples are kept in desiccator in order to allow uniform moisture distribution by preventing loss of moisture for 24 hours. The Test is conducted as per the specifications envisaged in IS 2720-Part 151986 [6]. The consolidometer has been placed in position in the loading device and adjusted suitably to take care of proper alignment. . The dial gauge is then clamped into position for recording the relative movement between the base of the consolidation cell and the loading cap. The consolidation cell has been filled with water. A seating pressure of $0.05 \mathrm{~kg} / \mathrm{cm}^{2}$ has been applied to the specimen. Accordingly, the test has been conducted applying monotonic loading.

\section{ANALYSIS OF TEST RESULTS}

The aim of the present paper is to bring out a step wise procedure to assess the compressibility behaviour of compacted soils. Accordingly the soil samples considered in the present investigations were subjected to monotonic loading. The test results are presented in Figures 1-2. The figure 4 represents the e- $\sigma$ v relationship whereas the figure 2 represents the e-log ov relationship. It may be observed (Figure 2) that the compressibility behaviour is characterised by two linear portions marked by a breaking point. Pressure at which the stiffness of the soil in the oedometer falls rapidly and slope of the e-log $\sigma \mathrm{v}$ curve shows a sudden change characterised by a breaking point, is termed as yield stress. The compression is negligible before yield stress followed by relatively high compressibility is seen up to very higher level of stress. Considering these two zones i.e negligible compressibility up to yield stress, and relatively higher compressibility beyond, is typical of over-consolidated soil. The compressibility of an over-consolidated soil is never greater than the normally consolidated state and it may just approach the normally consolidated state at higher stress levels. The same features are reflected for all eight samples tested. 


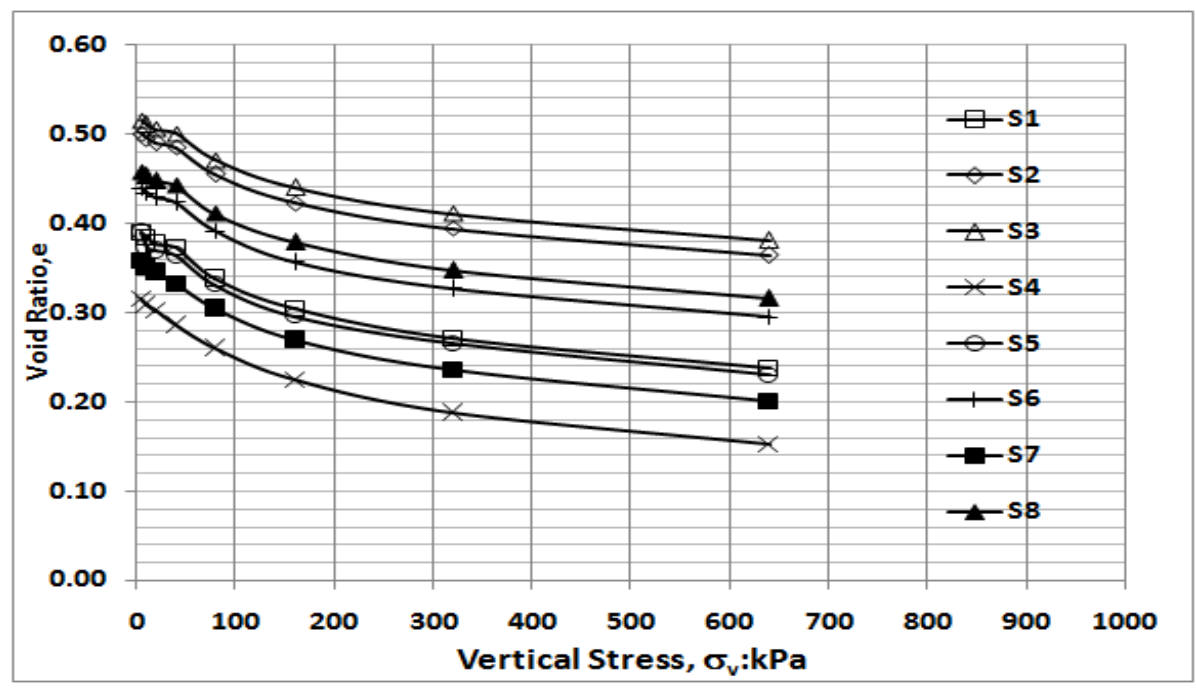

Figure 1 Compression paths of soils in 1-dimensional compression

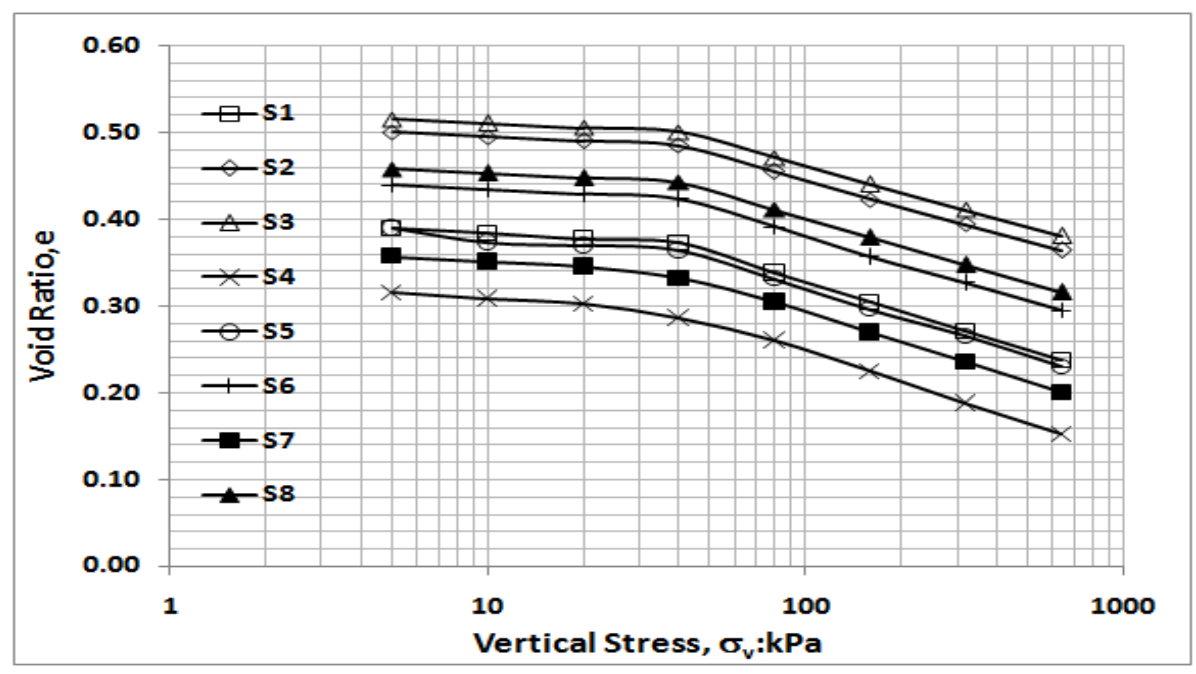

Figure 2 Compression paths of soils (log scale)

The post yield behaviour for all eight samples is shown n Figure 3.

The pre-consolidation pressure observed in oedometer test is the most familiar example of yielding of soils; similar patterns can be seen in unconfined compression test as shown in figure 3. An attempt has been made to examine the possibility of determining relationship between yield stress values in oedometer compression with yield stress values in unconfined compression. The relationship is presented in Figure 3. The relationship obtained is given by:

$$
\frac{\sigma_{y}}{q_{u}}=0.353-0.322\left(e_{0}\right) \quad \text { equation } 1
$$

Where, $\sigma_{\mathrm{y}}=$ yield stress in one dimensional compression

$\mathrm{q}_{\mathrm{u}}=$ unconfined compression strength and

$\mathrm{e}_{0}=$ initial void ratio

It may be seen that all the compression paths are linear. The spacing of compression paths is found to be in the order of their respective initial states. The compressibility behaviour is similar to the behaviour of normally consolidated soil, as given by intrinsic compression line, given by Nagaraj et al (1994) [12], as represented by the following linear equation: 


$$
\frac{e}{e_{L}}=1.122-0.234 \log _{10} \sigma_{v}
$$

Where $e_{\mathrm{L}}=$ void ratio at liquid limit.

However, the compression behaviour in compression post yield does not follow the path proposed by the above equation as is evident from the Figure 3. It turns out that the compression behaviour of compacted soils exhibit rigid response compared to normally consolidated soils.

The Compression paths of the compacted soils before the yield stress are presented in Figure 4. It is seen that the behaviour is one of rigid response with no significant volume change. However these paths are noticed to be spaced in the order of their initial void ratios.

An attempt has been made to find out the relationship between compression indices (CC1), before yield and CC2 after the yield stress. The data of only six samples have been used for the purpose of finding the correlations and the data of the other two samples have been used for predicting the compression paths.

The values of compression index (Cc2) are plotted together with their respective void ratios as shown in Figure 4. It may be seen that the relationship is found be linear with the following relationship, with a correlation coefficient of 0.988 :

$$
C_{c 2}=0.157-0.119\left(e_{0}\right)
$$

equation 2

The values of compression index $(\mathrm{Cc} 1)$ are plotted together with their respective void ratios as shown in Figure 5. It may be seen that the relationship is found be linear with the following relationship with a correlation coefficient of 0.986 :

$$
C_{c 1}=0.108-0.152\left(e_{0}\right) \quad \text { equation } 3
$$

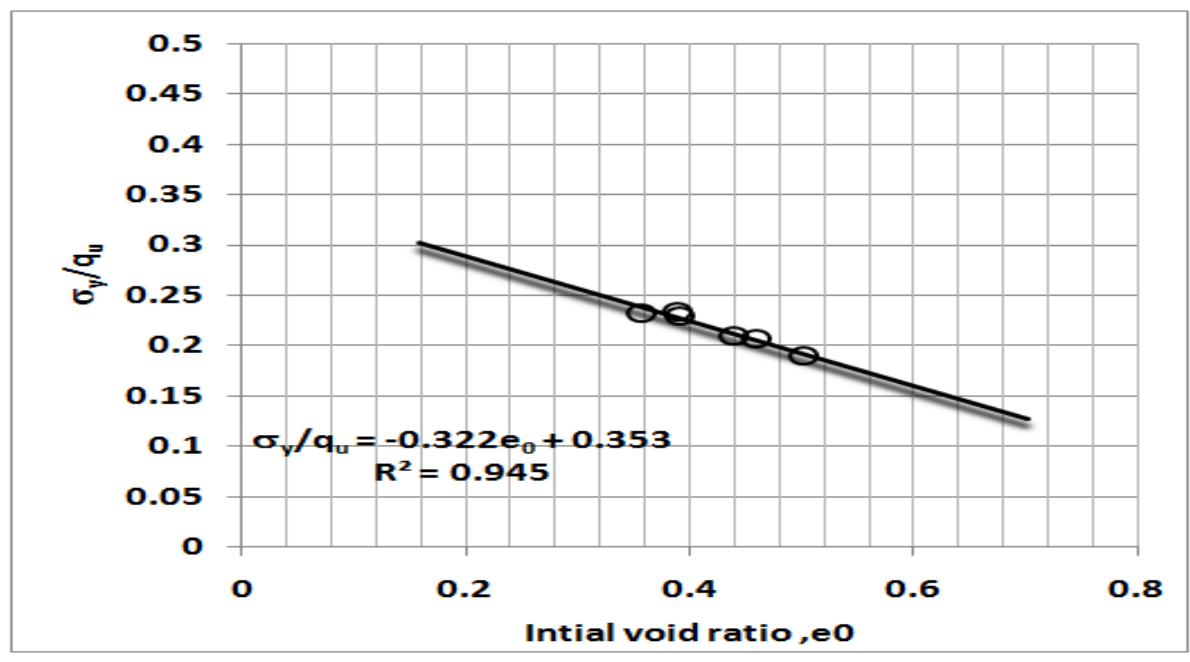

Figure 3 Normalised Yield stress values with initial void ratio 
U. Venkata Rathnam and Dr. K. Nagendra Prasad

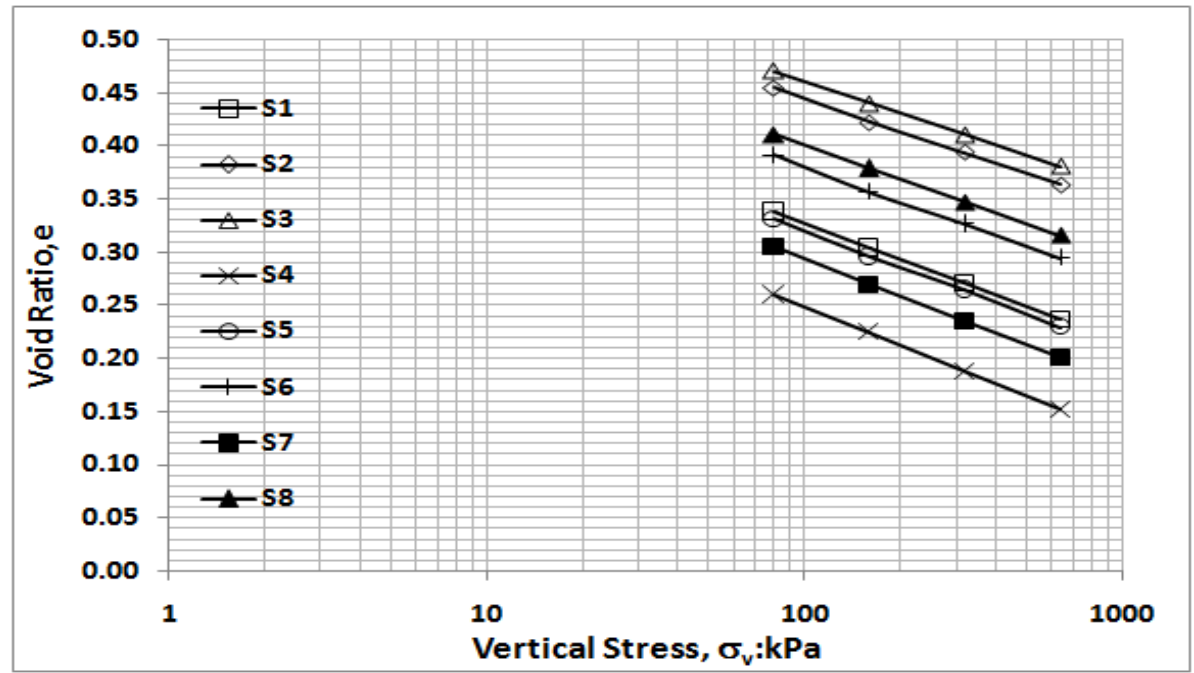

Figure 4 Compression paths of compacted soils after the yield stress

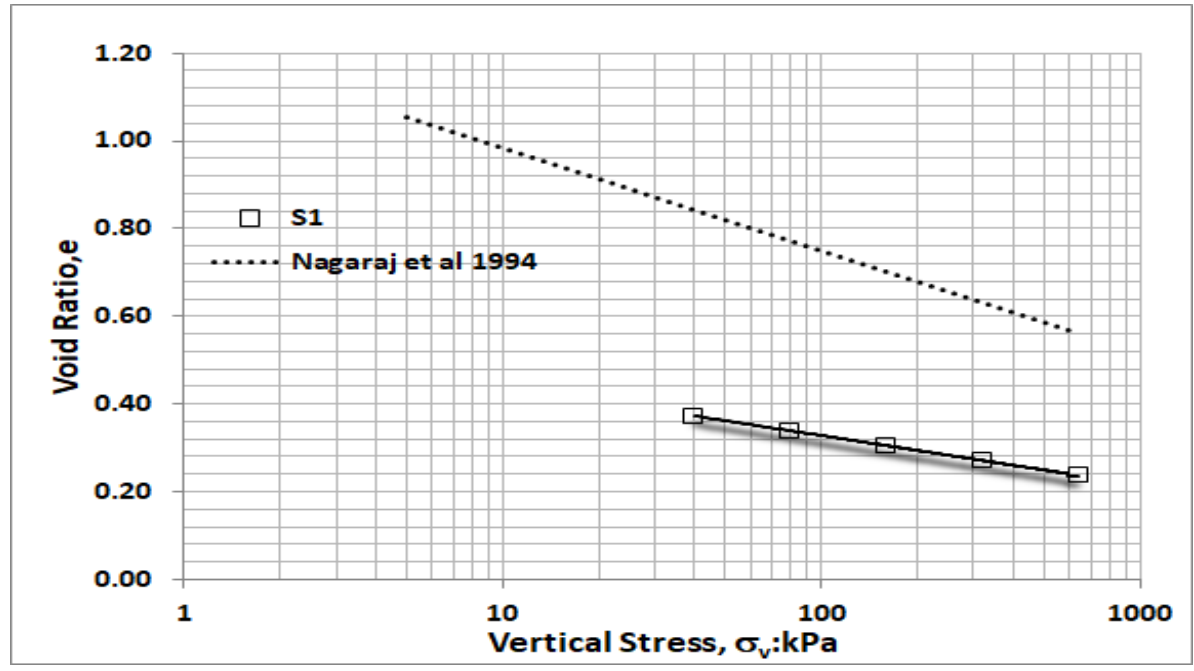

Figure 5 Compression paths of compacted soils post yield in relation to normally consolidated soils

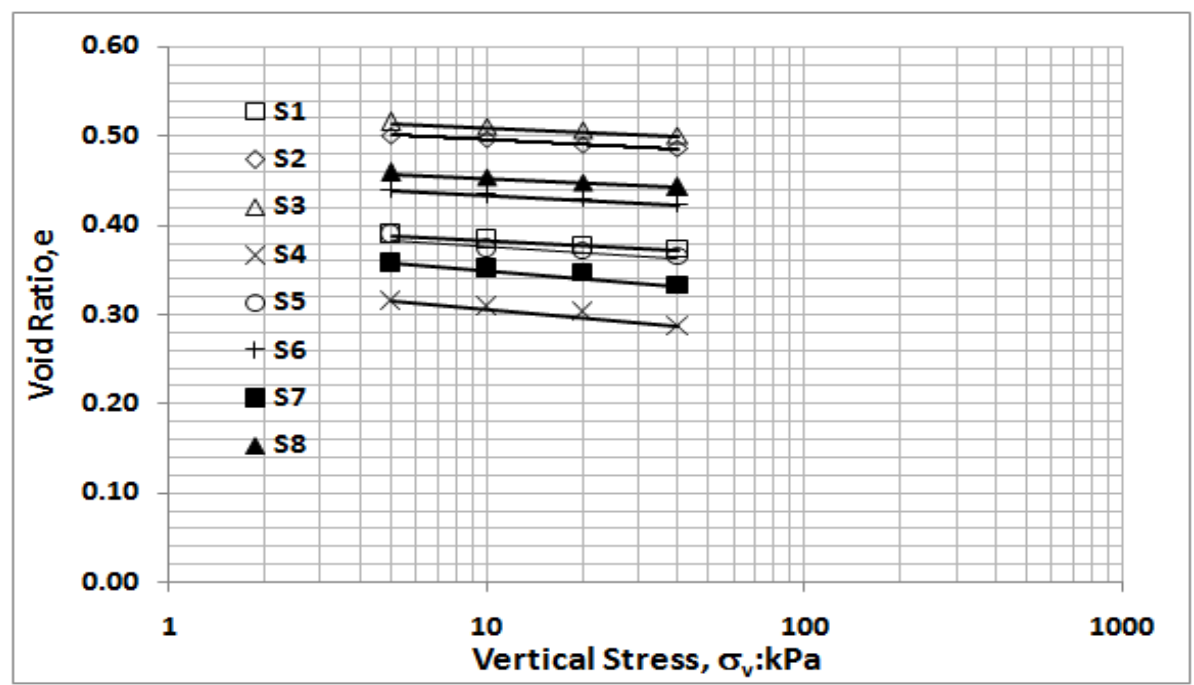

Figure 6 Compression paths of compacted soils before the yield stress 
Assessment of Compression Behaviour of Compacted Soils

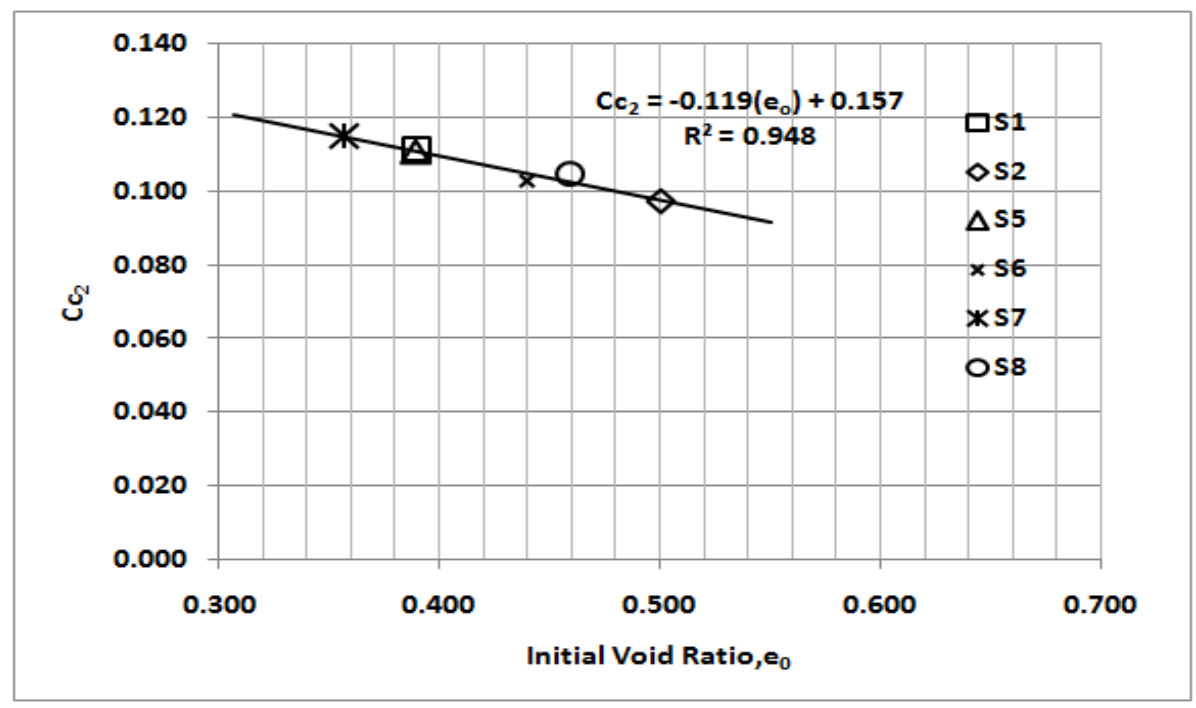

Figure 7 Relationship between Compression index $\left(\mathrm{Cc}_{2}\right)$ and initial void ratio

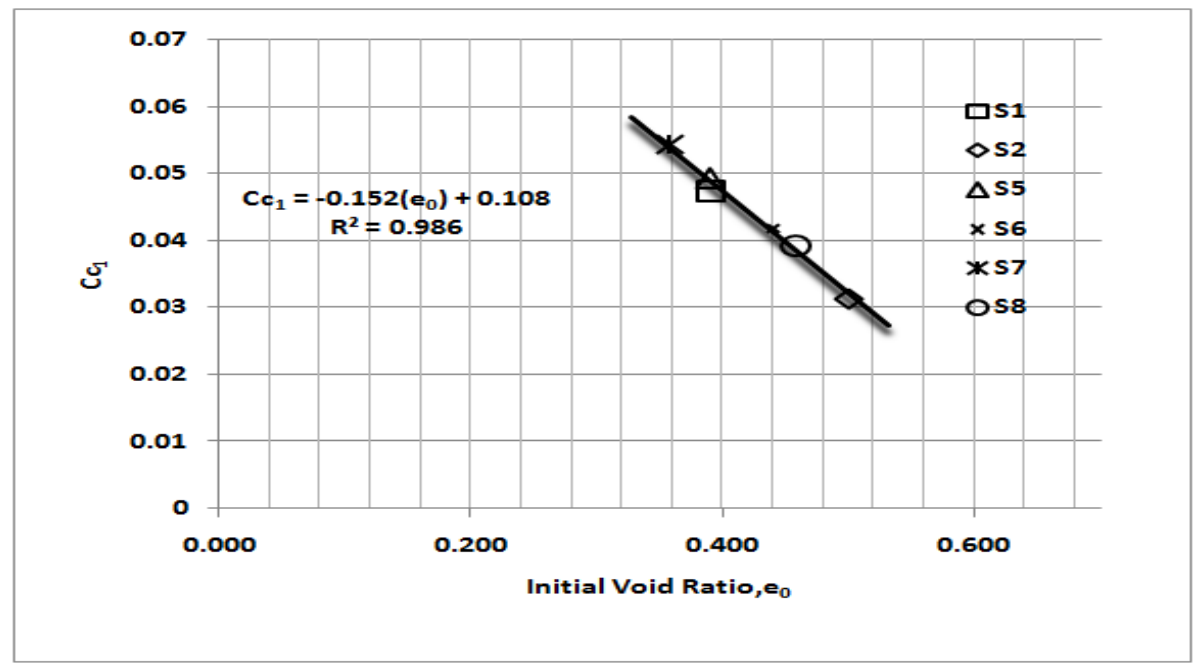

Figure 8 Relationship between Compression index $\left(\mathrm{Cc}_{1}\right)$ and initial void ratio

\subsection{Prediction of Compressibility Behaviour}

Equations 1, 2 and 3 may be used to predict the compressibility behaviour of compacted soils. The step-wise procedure is presented below:

\section{Step-1}

Determine $(\gamma \mathrm{d})_{\max }$ from standard Proctor's compaction test and hence the initial void ratio, $\left(\mathrm{e}_{0}\right)$

\section{Step-2}

Determine $\sigma y$ from equarion1, knowing unconfined compressive strength, $\mathrm{q}_{\mathrm{u}}$ and initial void ratio $\left(\mathrm{e}_{0}\right)$

Step-3

Determine $\mathrm{Cc} 2$ from equation 2 and $\mathrm{Cc} 1$ from equation 3, knowing initial void ratio (e0)

\section{Step-4}

Determine the compression path as given by: 


$$
\begin{aligned}
& e=e_{0}-C_{c 1} \log \left(\frac{\sigma_{0}+\Delta \sigma}{\sigma_{0}}\right) \quad \text { if } \quad \sigma_{v} \leq \sigma_{y} \\
& e=e_{0}-C_{c 2} \log \left(\frac{\sigma_{0}+\Delta \sigma}{\sigma_{0}}\right) \quad \text { if } \quad \sigma_{v} \geq \sigma_{y}
\end{aligned}
$$

The data of two samples whose values were not used in the development of equations 1-3 has been used for predicting the compression paths as shown I Figure 9. Similarly, the data of Baiji dune ( Abbas and Yousif, 2017) [1] soil and Tuzla (Sridharan and Yesim, 2005) [16] soil has also been used for prediction purposes ( Figures 10-11). A sample calculation of predicted values is shown in Table 3.

Table 3 Prediction of compression paths

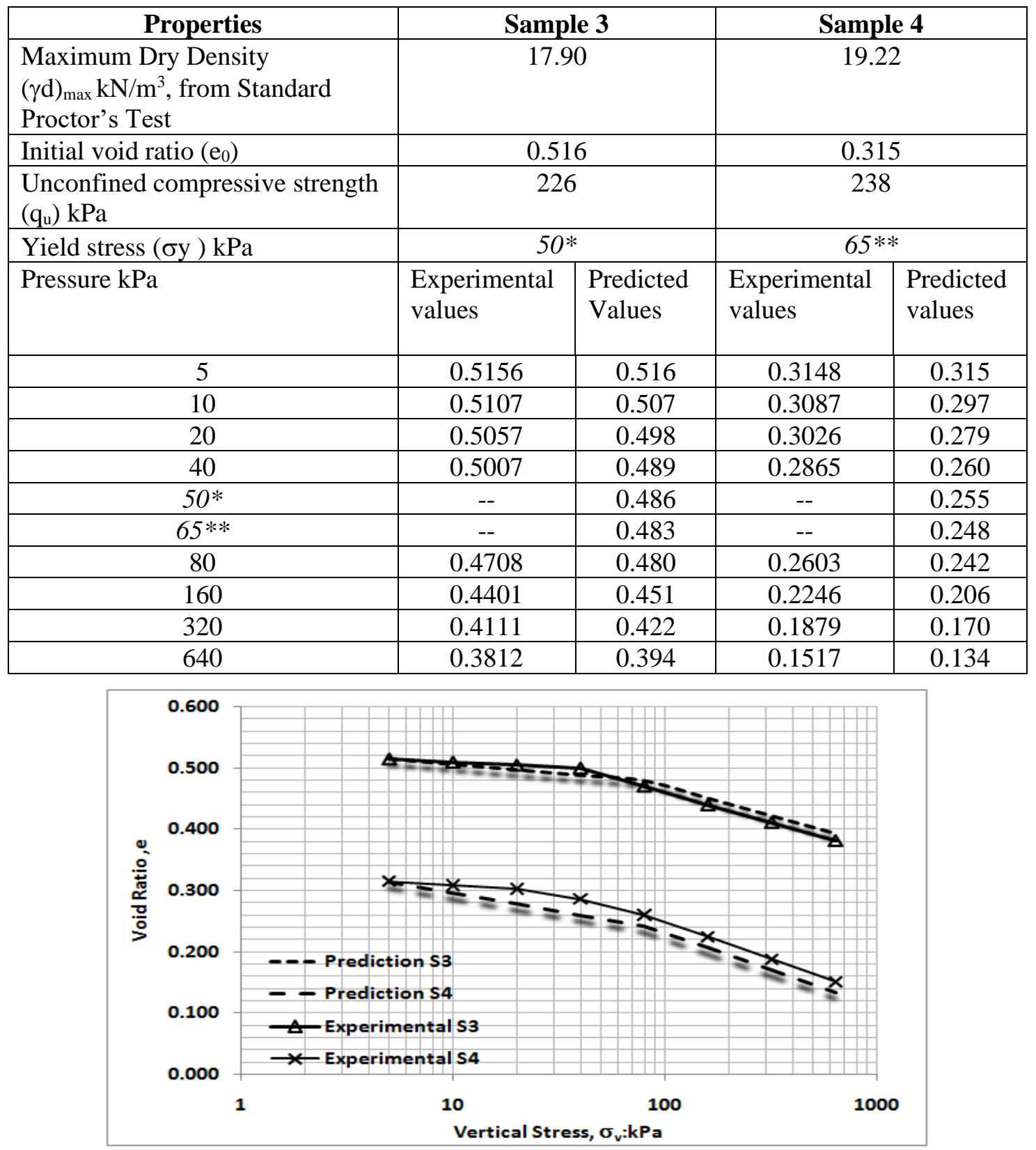

Figure 9 Predicted vs. Experimental values 


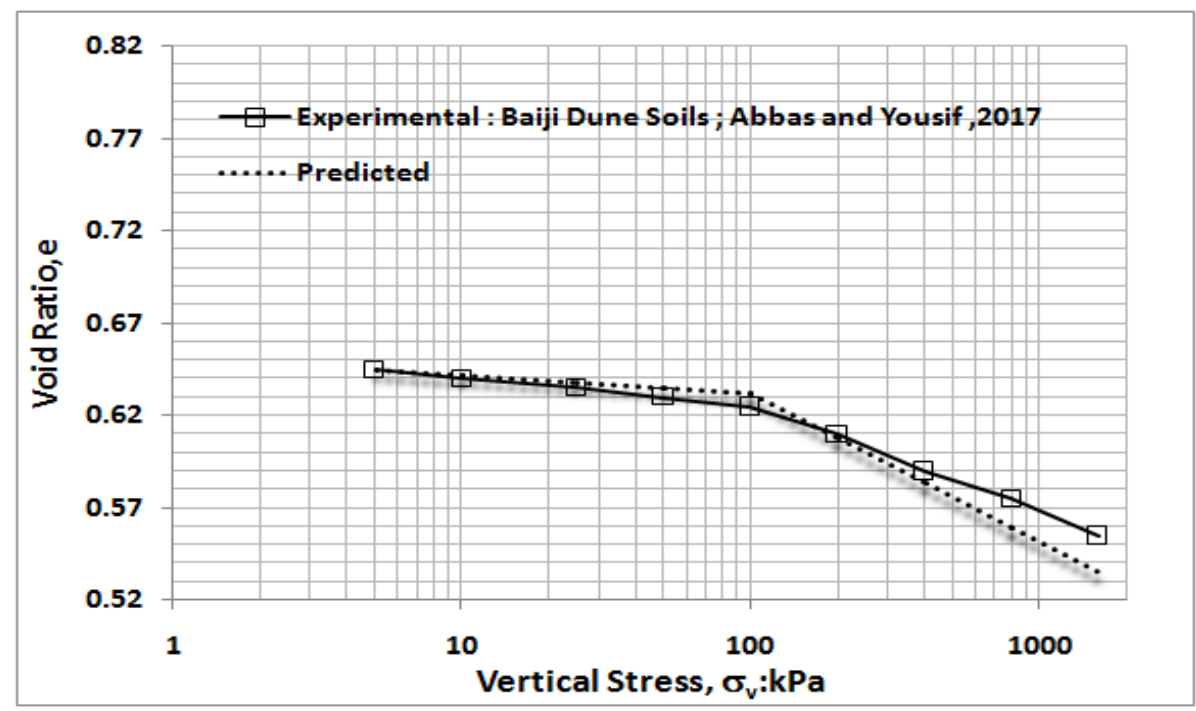

Figure 10 Predicted vs. Experimental values for Baiji Dune Soils

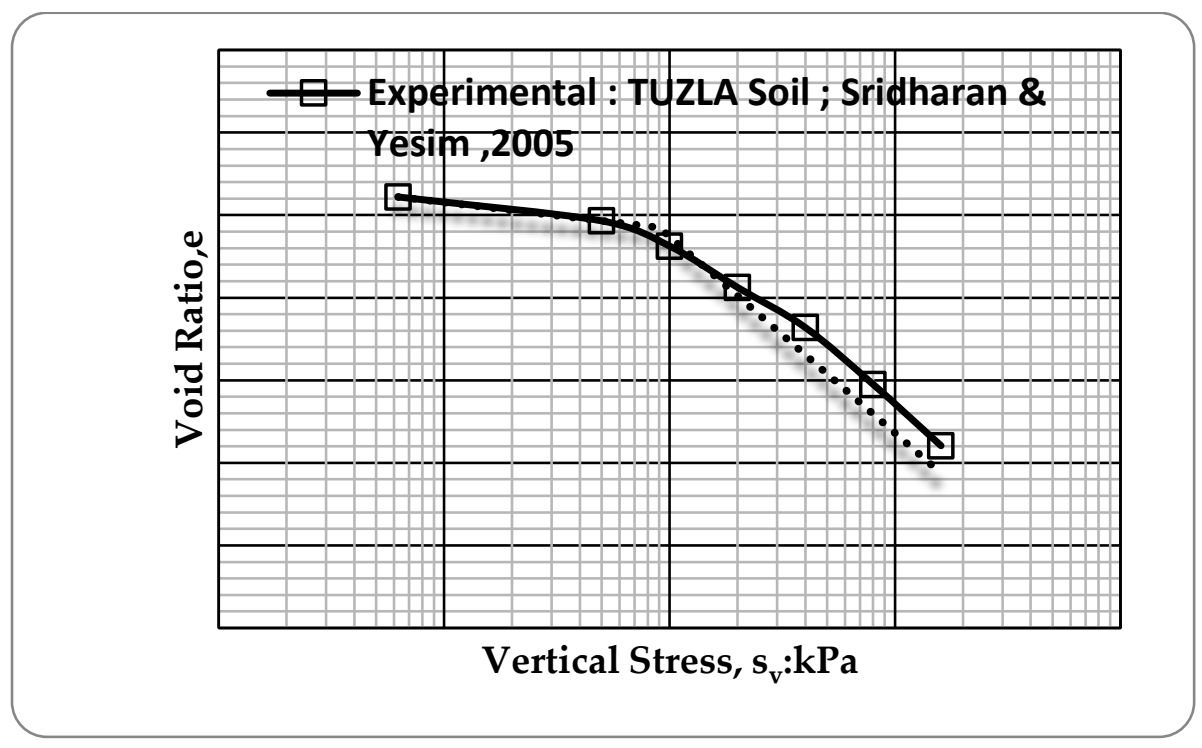

Figure 11 Predicted vs. Experimental values for Tuzla Soils

\section{CONCLUDING REMARKS}

Based on experimental investigation \& analysis of test results the following concluding remarks are made:

- Sample, when subjected to one dimensional compression by increasing normal stress, a yield point is observed where the stiffness of the sample changes rapidly.

- The compression behavior of compacted soils in oedometer exhibit bilinear compression paths characterising pre-yield and post yield response.

- The compression behavior before yield shows rigid response with small deformations, whereas, the compression behavior post yield shows relatively greater deformations.

- The yield behavior is noticed in unconfined compression test as well, with the yield stress values in 1-D and unconfined compression bearing the following relationship:

$$
\frac{\sigma_{y}}{q_{u}}=0.353-0.322\left(e_{0}\right) \quad \text { equation } 1
$$


- The values of compression index before yield and after yield show the following relationships

$$
\begin{array}{ll}
C_{c 2}=0.157-0.119\left(e_{0}\right) & \text { equation } 2 \\
C_{c 1}=0.108-0.152\left(e_{0}\right) & \text { equation } 3
\end{array}
$$

- Initial void ratio is the key factor in determining the compression behavior and stress behavior.

- The prediction of compression behavior of soils (from the following equations) tested in the present investigation and the published literature agree quite satisfactorily, bringing out the merit of the proposed approach.

$$
\begin{aligned}
& e=e_{0}-C_{c 1} \log \left(\frac{\sigma_{0}+\Delta \sigma}{\sigma_{0}}\right) \quad \text { if } \quad \sigma_{v} \leq \sigma_{y} \\
& e=e_{0}-C_{c 2} \log \left(\frac{\sigma_{0}+\Delta \sigma}{\sigma_{0}}\right) \quad \text { if } \quad \sigma_{v} \geq \sigma_{y}
\end{aligned}
$$

\section{ACKNOWLEDGEMENTS}

The authors place on record their sincere gratitude to S.V. University, Tirupati, AP, for having provided the laboratory and computational facility while carrying out the research work cited in the present paper

\section{REFERENCES}

[1] Abbas Jawad Al-Taie and Yousif J. Al-Shakarchi. (2017) "Shear Strength, Collapsability and Compressibility Characteristics of Compacted Baiji Dune Soils", Journal of Engineering Science and Technology, vol. 12, No. 3 (2017) 767-779.

[2] Akayuli, C.F.A., Ofosu, Bernard (2013), "Empirical Model for Estimating Compression Index from Physical Properties of Weathered Birimian Phyllites", Electronic Journal of Geotechnical Engineering, vol.18, pp. 6134-6144.

[3] Chao Yang, John P. Carter, and Daichao Sheng. (2014) "Description of compression behaviour of structured soils and its application", can. Geotech. J 51:1-13.

[4] Indian Standard Classification and identification of soils for general engineering purposes. IS:1498-1970.

[5] Indian Standard Method of test for soils part 1 preparation of dry soil samples for various tests. IS:2720 (part1).1983, Bureau of Indian Standard.

[6] Indian Standard Method of test for soils part 15 Determination of consolidation properties. IS:2720 (part15).1986, Bureau of Indian Standard.

[7] Indian Standard Method of test for soils part 3 determination of specific gravity Section 1 Fine Grained Soils. IS:2720 (part3).1980, Bureau of Indian Standard.

[8] Indian Standard Method of test for soils part 4 Grain size analysis. IS:2720 (part4).1985, Bureau of Indian Standard.

[9] Indian Standard Method of test for soils part 40 Determination of free swell index of soils. IS:2720 (part40).1985, Bureau of Indian Standard. 
[10] Indian Standard Method of test for soils part 5 Determination of liquid limit and plastic limit. IS:2720 (part5).1985, Bureau of Indian Standard.

[11] Indian Standard Method of test for soils part 7 Determination of water content-dry density relation using light compaction. IS:2720 (part7).1980, Bureau of Indian Standard.

[12] Nagaraj, T.S., N.S. Pandian, and P. S. R. Narasimha Raju. 1994. Stress-state-permeability relations for over consolidated clays. Geotechnique 44 (2): 349 - 352.

[13] Nagendra Prasad. K, Manohara Reddy, R., Chandra, B \& Haarsha Vardan Reddy, M (2013)" Compression Behaviour of Natural Soils", International Journal of Civil Engineering and Technology (IJCIET), ISSN 0976-6308 (Print), ISSN 0976-6316 (Online), pp 80-91, Volume 4, Issue 3, May - June (2013). ( IAEME

[14] Rakesh Kumar Jain P.K., Pundreek Dwivedi, (2016). "Prediction of Compression Index (Cc) of Fine Grained Remolded Soils from Basic Soil Properties". International Journal of Applied Engineering Research ISSN 0973-4562 Volume 11, Number 1 (2016) pp 592-598 (C) Research India Publications. http://www.ripublication.com.

[15] Rehman Zia ur., Usma Khalid, Khalid Farooq and Hassan Mujtaba. (2018) "On yield stress of compacted clays", International Journal of Geo-Engineering 9:21. DOI 10.1186/s40703-018-0090-2.

[16] Sridharan A., and Yesim Gurtug (2005) "Compressibility characteristics of soils", Geotechnical and Geotechnical Engineering 23: 615-634. DOI 10.1007/s10706-004-91122.

[17] Tiwari, B. T. and Ajmera, B. (2012). "New Correlation Equations for Compression Index of Remolded Clays.” J. Geotech. Geoenviron. Eng., 138(6), pp. 757-762.

[18] Venkata Ratnam U., Nagendra Prasad K., (2019) "Prediction of Compaction and Compressibility Characteristics of Compacted Soils", International Journal of Applied Engineering Research, ISSN 0973-4562 volume14, Number 3, pp. 621-632. 